\title{
Miranda
}

Revue pluridisciplinaire du monde anglophone /

Multidisciplinary peer-reviewed journal on the English-

speaking world

$23 \mid 2021$

Modernist Exceptions

\section{"Making Space in Cyprus for Art and Activism": An Interview with Ellada Evangelou}

Interview

Leslie Frost

\section{(2) OpenEdition}

Journals

Electronic version

URL: https://journals.openedition.org/miranda/43185

DOI: 10.4000/miranda.43185

ISSN: 2108-6559

\section{Publisher}

Université Toulouse - Jean Jaurès

Electronic reference

Leslie Frost, "'Making Space in Cyprus for Art and Activism": An Interview with Ellada Evangelou", Miranda [Online], 23 | 2021, Online since 15 October 2021, connection on 29 November 2021. URL: http://journals.openedition.org/miranda/43185 ; DOI: https://doi.org/10.4000/miranda.43185

This text was automatically generated on 29 November 2021.

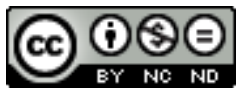

Miranda is licensed under a Creative Commons Attribution-NonCommercial-NoDerivatives 4.0 International License. 


\title{
"Making Space in Cyprus for Art and Activism": An Interview with Ellada Evangelou
}

Interview

\author{
Leslie Frost
}

\section{Websites}

Rooftop Theatre Group: https://www.rooftoptheatregroup.com/

Home for Cooperation: https://www.home4cooperation.info

Buffer Fringe: https://bufferfringe.org/

\section{Biography of Ellada Evangelou}

4 Born and raised on the island of Cyprus, Ellada Evangelou has been the Creative and Artistic Director of the Buffer Fringe Performing Arts Festival in the divided city of Nicosia, Cyprus, since 2019. Long at the forefront of the Cypriot performing arts scene, Evangelou has worked as a dramaturg, theatre director, and independent consultant in collaboration with theatre companies, NGOs, and international organizations, including UNDP and the Anna Lindh Foundation. She is the co-founder of Rooftop Theatre, a member of the Leadership Circle of the IMPACT Project, and a 2020 Global Fellow of the International Society for the Performing Arts. Evangelou teaches theatre and dramaturgy courses in higher education in Cyprus and the United States. She is interested in the relationship between theater/dramaturgy and identity and works in the intersection of ARTivism and scholarship in post-colonial, post-conflict communities. 


\section{Interview}

Figure 1

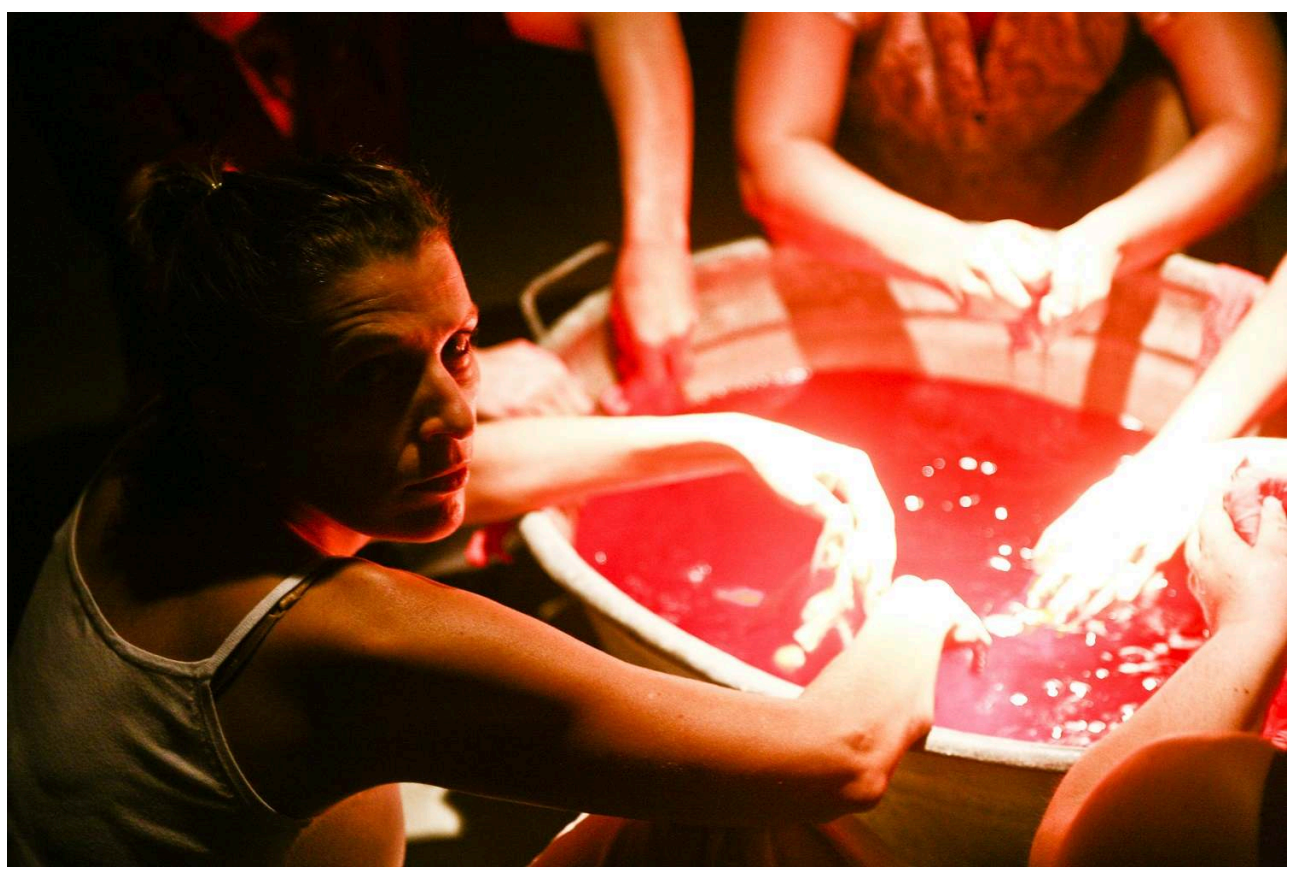

(Rooftop Theatre Group, 2012),

A scene from The Hand Diaries (Rooftop Theatre Group, 2012), directed by Ellada Evangelou of captured women washing their clothes in menstrual blood in a collective effort to avoid rape.

Credits: Panagiotis Mina

Leslie Frost: Ellada, thank you so much for agreeing to be interviewed.

Ellada Evangelou: Thank you for the invitation! I am happy to be speaking with you and sharing experiences and views with the audience of "Ariel's Corner." It's not often that we connect across the ocean, so this makes me very happy!

L.F.: Me too! Your performance work in Cyprus has showcased art at the intersection of performance and ARTivism. As the Buffer Fringe Performing Arts Festival creative director, what is your vision?

EE: Cyprus is a small island in the eastern Mediterranean, close to so many places that have experienced colonialism and violence over the past 200 years. There has also been a fair amount of tension on the island itself, since as a British Colony and then more recently as an independent republic, it has seen the rise of nationalism and intercommunal violence between Greek Cypriots and Turkish Cypriots. It is now in a (peaceful) frozen conflict for over 50 years.

Such places that thrive on things remaining unchanged require that artistic creation serve as a constant reminder of the multiple narratives that have emerged through all the different experiences of the people living permanently or passing through. Small places tend to close up and to refuse to see how colonization and conflict affects individuals and groups. Theatre and performance inevitably need to serve as reminders; they need to provide the space for communities and artists to come in contact, and to present the fruit of their conversations on the stage, to be shared with a public. 
Therefore, my vision has been to provide or create that space, through time and from different vantage points. As a theatre maker I have engaged with groups whose voices are more rarely heard, such as migrants passing through the island, stuck in camps unable to move. Moreover, through the work of Rooftop Theatre Group, a bicommunal performing arts-based NGO, we have used the testimonies of marginalized individuals from the period of violence in Cyprus (1963-74), as a basis for building performances and actions.

As an academic, my vision is to shine light on the unknown and unexplored dramaturgies of the island. I do this by writing and connecting performance to identities and cultures across time. This illuminates the many folds of history on an island with written and oral literature in Greek, Turkish, Cypriot Greek, and Cypriot Turkish, and to a lesser extent in Armenian and Cypriot Maronite Arabic (Sanna).

L.F.: The Buffer Fringe Festival held its first event in 2014. Would you tell us about its history?

EE: Sure. The history of the Buffer Fringe festival is interlinked to the history of a space, the Ledra Palace crossing between the two communities of the island, between the north and south. The crossing, a street stretching several hundred feet, was named after the famous hotel situated in it, Ledra Palace, built in the 1940s with the limestone that characterizes much of the architecture of the Levant. The hotel was converted into a barracks for the UN forces guarding the dividing line after 1974.

The Ledra Palace crossing was re-opened for civilians to cross to the other side of the dividing line in 2003. Once opened it reconnected the Greek Cypriots living on the south side of the divide, and the Turkish Cypriots to the north. There were many in these populations that wanted to get to know each other again and to co-create. The Home for Cooperation is a community center and NGO home that was founded in 2011 to facilitate connection. The H4C, as its known, established the Buffer Fringe Performing Arts Festival in 2014, as a means to host collaborations between GreekCypriot and Turkish-Cypriot performing artists. Two years later, the Festival became international and connected to the broader Fringe family. Since then it has hosted dozens of productions, workshops, collaborative work, and has continued to challenge the boundaries of theatre and performance. Moreover, the participatory nature of much of the work, is important as it serves as an antipode to the top-down approach of social workings and decision-making.

L.F.: You have a long commitment to the arts and to grassroots activism as a founder and current board resident of Rooftop Theatre. What was the impetus for the Rooftop Theatre's founding?

EE: Returning from my studies in the US in 2002, I experienced firsthand the opening of the checkpoints, and for the first time I had the chance to work with my compatriots, whom I had never met before, Turkish-Cypriots who had grown up on the other side of the dividing line. Founding Rooftop Theatre was a step in making sure that from then and until this day, through the activities of the Group, we continue to stand for inclusion and openness to stories, methodologies, and collaborations. At times it's tough and administrations or groups on either side of the dividing line are not friendly to our activities, but we continue to evolve, exploring other ways to create together. 
L.F.: How do your experiences with Rooftop and other performance events in Cyprus ground your work with the Buffer Fringe Festival?

EE: Participating in an NGO and running a Festival are different but (for me) connected paths. At the end of the day, as I said at the beginning, it's about making space for creation. Through the work of Rooftop, I realized how many people and groups want to participate and be part of something, but they may not realize how they can do this or are too hesitant to try. It's important to first acknowledge and express the value in each individual story, as a means to instill confidence in people to move forward.

This is especially true for women, both younger and older, who are reluctant to come forward, and share what they have gone through. Patriarchal societies such as ours, with the cloak of modernization and European identity thrown over conservative behaviors, consistently negate the experiences of women as unimportant. Women are expected to either be martyrs, suffering quietly for the fate of their families or their own, or objects of desire, impeccable and virtuous. Young female artists or mixed groups of women and men are starting to explore this further, to try to find its roots, deconstruct it and to embrace new identities, new desires, or embrace old ones in new ways. We are especially happy to make space for that.

\section{L.F.: What can we expect to see in October 2021 ?}

EE: Carrying on with the theme of 'Displacement' into 2021 complements and expands the creative, artistic and thinking processes that started in 2020. This running year will include postponed works from 2020, as well as new works and partnerships/ collaborations. The festival will take place physically in spaces in Nicosia (venues in the north and south of the city), in Famagusta, and online, with the showing of live performances online also.

Taking the past year's experiences into consideration, the hybrid approach of the festival allows the artists to bring a new dimension to the ongoing work. The Festival still entails a strong work-in-progress component and fosters several innovative approaches in order to support artists, provide a creative thinking space and to develop new audiences, giving a chance for the theme to come full circle. An example is the "95 Steps" project, a dynamic collaboration between the Mitos Performing Arts Center (Limassol) and Magusa Kale Pasaji (Famagusta), artists collective with inspiring work in their own rite. During the 2020 festival, they created a virtual mapping of the current experience of Limassol and Famagusta, coastal cities experiencing similar economic and ecological trends, relating to tourism and development, as well as a connectedness as to the refugees that had left the one area and moved to the other, through a map with 95 stops starting from Limassol, symbolizing the $95 \mathrm{kms}$ between them. In 2021, starting from Famagusta, they are making a second mapping, looking at the process from the 'other' side, completing the work with an online sound installation, relating to the current experience of Famagusta and its relationship to Limassol.

These festival elements feature in the Buffer Fringe blog, a space for information, documentation and sharing by artists, Thinking Partners and supporting organizations. ${ }^{1}$

Through the Buffer Fringe, our aim is to foster the spirit of solidarity also through parallel events such as a conference to unpack support mechanisms for festivals and 
to further elaborate on how Covid-19 affected artists, the arts and the cultural sector. We believe that this is of particular importance to understand and re-create the future of the arts and festivals after the Covid-19 crisis.

Through the Buffer Fringe, we are proposing a festival that constantly evolves, is in dialogue and interaction with individuals and groups, and thrives in its critical approach to curation and community engagement.

\section{Figure 2}

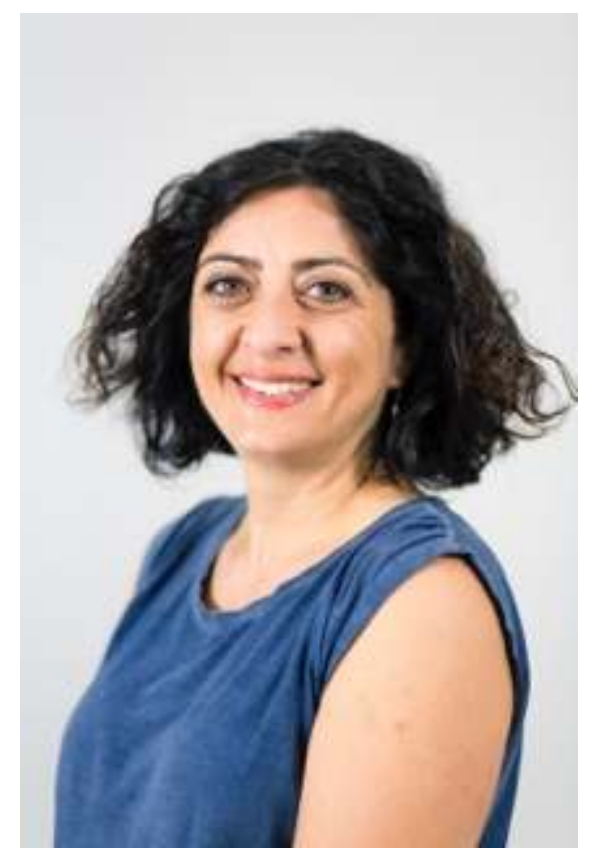

Ellada Evangelou.

Credits: Panagiotis Mina

\section{NOTES}

1. Thinking Partern : https://bufferfringe.org/.

\section{ABSTRACTS}

Interview with Ellada Evangelou. The interview occurred during preparations for the eighth annual Buffer Fringe Performing Arts Festival 2021 to be held October 8-10 in Nicosia, Cyprus. 
Entretien avec Ellada Evangelou. L'échange a été conduit lors des préparatifs du huitième festival annuel Buffer Fringe Performing Arts Festival 2021 qui se tiendra du 8 au 10 octobre à Nicosie, Chypre.

INDEX

Subjects: Theater

Keywords: Ellada Evangelou, Cyprus, ARTivism, Buffer Fringe Performing Arts Festival, Rooftop Theatre Group

Mots-clés: Ellada Evangelou, Cyprus, ARTivisme, Buffer Fringe Performing Arts Festival, Rooftop Theatre Group

\section{AUTHOR}

\section{LESLIE FROST}

Teaching Associate Professor

University of North Carolina at Chapel Hill

lefrost@email.unc.edu 